\title{
City of Bingöl in May 2003: Assessment of strong ground motion records
}

\author{
U ÇEKEN ${ }^{1}$, G BeyHaN ${ }^{2}$ and H H SELIM ${ }^{3, *}$ \\ ${ }^{1}$ Prime Ministry, Disaster and Emergency Management Presidency, Earthquake Department, \\ 06520, Ankara, Turkey. \\ ${ }^{2}$ Department of Geophysical Engineering, Sakarya University, 54187, Sakarya, Turkey. \\ ${ }^{3}$ Department of Jewellery Engineering, Istanbul Commerce University, 34840, Istanbul, Turkey. \\ *Corresponding author.e-mail: hselim@ticaret.edu.tr;haluk.selim@gmail.com
}

The main shock of Bingöl earthquake $\left(M_{W}=6.4\right)$ recorded by six accelerometers in the area occurred at 03:27 local time on May 1, 2003. The largest acceleration value of north-south component was recorded as $545.5 \mathrm{~cm} / \mathrm{s}^{2}$ at the nearest station which is $12 \mathrm{~km}$ away from the epicenter of earthquake. Especially, $0.15 \mathrm{~s}$ short period was observed when high spectral acceleration value occurred. An acceleration value greater than 50 gal was recorded at the BNG (Bingöl) station and structural damage occurred within $6.5 \mathrm{~s}$ was very important for the near source and strong ground motion seismology. The recorded peak acceleration values were greater than the estimated empirical acceleration values. However, the structural damage was not as high and widespread as expected. This occurrence was explained by considering the factors of earthquake source, frequency content, effective duration, effective acceleration value, local soil conditions, rupture direction and attenuation.

\section{Introduction}

The May 1, 2003 Bingöl earthquake occurred $12 \mathrm{~km}$ north of Bingöl at 03:27 local time. The moment magnitude $\left(M_{W}\right)$ of earthquake was calculated to be 6.4 by KOERI (Kandilli Observatory and Earthquake Research Institute). The earthquake took place in an area close to the intersection of the left lateral East Anatolian Fault (EAF) and right lateral North Anatolian Fault (NAF). Distribution of the aftershocks (figure 1) indicated that Sudüğunü fault which is a secondary fault and perpendicular to the EAF generated the earthquake. The depth of focus was $10 \mathrm{~km}$. The casualties in the earthquake were 177 dead and 520 injured. The numbers of collapsed and heavily damaged buildings were 82 and 1602, respectively. The majority of the casualties happened in the Çeltiksuyu primary school. 114 students lost their lives in the school. An earthquake that previously occurred on May 22, 1971 at the city center of Bingöl killed 881 people (Tezcan and Bal 2003).

The main shock of the Bingöl earthquake was recorded by six strong-motion stations operated by the Disaster and Emergency Management Presidency Earthquake Department (DEMP-ED). The epicenter of the Bingöl earthquake has the closest distance to a station, which was ever recorded in Turkey. The Bingöl station (BNG) was closest to the main shock with epicentral distance of about $12 \mathrm{~km}$, and recorded two horizontal and vertical PGA values 545.5, 276.8 and $472.3 \mathrm{~cm} / \mathrm{s}^{2}$, respectively. The $545.5 \mathrm{~cm} / \mathrm{s}^{2}$ (gal) horizontal PGA is one of the largest ground acceleration peaks

Keywords. Bingöl earthquake; strong motion; peak acceleration; evaluation of damping; neotectonic. 


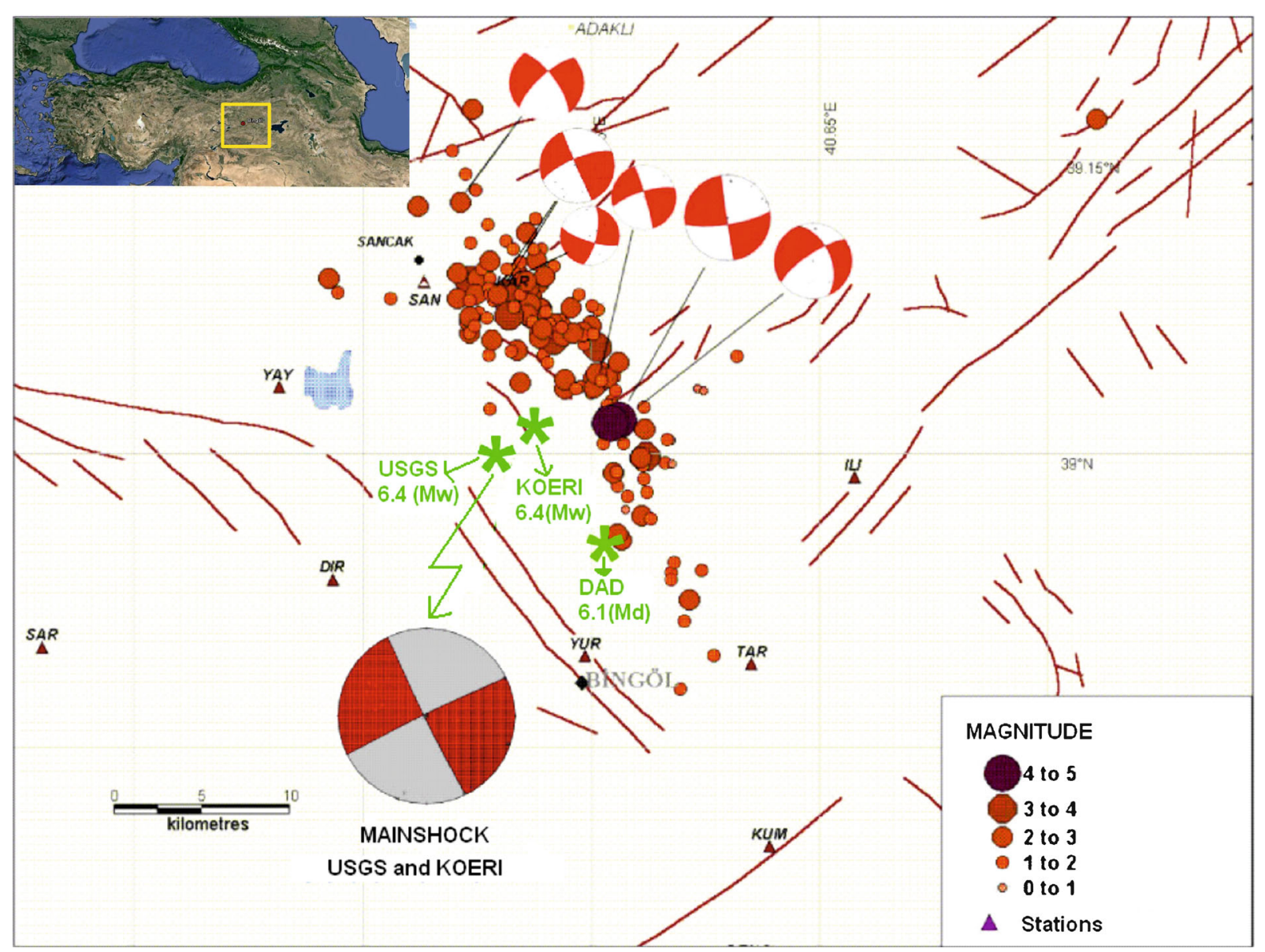

Figure 1. Aftershock distributions of Bingöl earthquake (between 11 and 13 May) and fault plane mechanism solutions (Zünbül et al. 2004).

recorded in Turkey, and its seismological features and effects on structures deserve to be scrutinized further. In addition, five temporary accelerometers were established to record the aftershocks. One of the instruments was set on the fourth floor of the Bingöl Public Works and Settlement Directorate building. The 2003 Bingöl earthquake occurred in the East Anatolian Fault Zone one of the main tectonic lines in Turkey. This fault system joins with the NAF and Bitlis-Zagros Suture Zone in Karlıova, Bingöl, which create the triple junction. The 2003 Bingöl earthquake is very close to the triple junction system. The earthquake was tectonically related to the triple junction system. The purpose of the study is to analyze the strong ground motion data recorded during the earthquake. The importance of the study is to evaluate the earthquake recorded in near field in Turkey. The main shock acceleration records of Bingöl earthquake were analyzed by this study. Also, the strong motions of aftershocks recorded in various types of soils were evaluated. Dynamic properties of soils underneath the permanent and temporary acceleration stations were also determined.
Microtremor and seismic refraction methods were used to determine dynamic properties.

\section{Strong motion records}

The main shock of the May 1, 2003 Bingöl earthquake was recorded by six stations (Bingöl - BNG, Tercan - TER, Erzincan - ERC, Elaziğ - ELZ, Tatvan - TAT, Malazgirt - MLZ) in the region. These accelerometers are located within $12-180 \mathrm{~km}$ to the epicenter of the earthquake. Table 1 presents the coordinates of stations and three component acceleration amplitude values of strong motion. Figure 2 shows the location of stations and maximum horizontal peak acceleration values. The BNG station which is $12 \mathrm{~km}$ away from the epicenter recorded the peak acceleration values of $545.5 \mathrm{~cm} / \mathrm{s}^{2}$ in north-south direction, $276.8 \mathrm{~cm} / \mathrm{s}^{2}$ in east-west direction and $472.3 \mathrm{~cm} / \mathrm{s}^{2}$ in vertical direction. This station is mounted on a special concrete table inside one-storey building located behind the Bingöl Prosperity and Housing Management. This building is located in the new-part of the 
Table 1. Accelerations stations recorded May 1st, 2003 Bingöl earthquake and recorded maximum acceleration values.

\begin{tabular}{|c|c|c|c|c|c|c|c|}
\hline \multirow[b]{2}{*}{ Station } & \multicolumn{2}{|c|}{ Coordinate } & \multirow[b]{2}{*}{ Soil } & \multirow{2}{*}{$\begin{array}{c}\text { Distance } \\
(\mathrm{km})\end{array}$} & \multicolumn{3}{|c|}{ Maximum acceleration $\left(\mathrm{cm} / \mathrm{s}^{2}\right)$} \\
\hline & $\overline{\text { North }}$ & East & & & $\overline{\mathrm{N}-\mathrm{S}}$ & $\mathrm{E}-\mathrm{W}$ & Vertical \\
\hline $\mathrm{BNG}$ & 39.29 & 41.01 & Hard & 12 & 45.5 & 226.8 & 472.3 \\
\hline TER & 39.78 & 40.39 & Hard & 88 & 5.1 & 10.3 & 4.3 \\
\hline $\mathrm{ERC}$ & 39.74 & 39.51 & Alluvium & 116 & 8.9 & 9.7 & 4.4 \\
\hline ELZ & 38.67 & 39.13 & Alluvium & 114 & 8.0 & 7.0 & 5.0 \\
\hline TAT & 38.49 & 42.27 & Hard & 167 & 6.0 & 4.2 & 3.0 \\
\hline MLZ & 39.17 & 42.54 & Alluvium & 180 & 5.0 & 5.5 & 3.0 \\
\hline
\end{tabular}

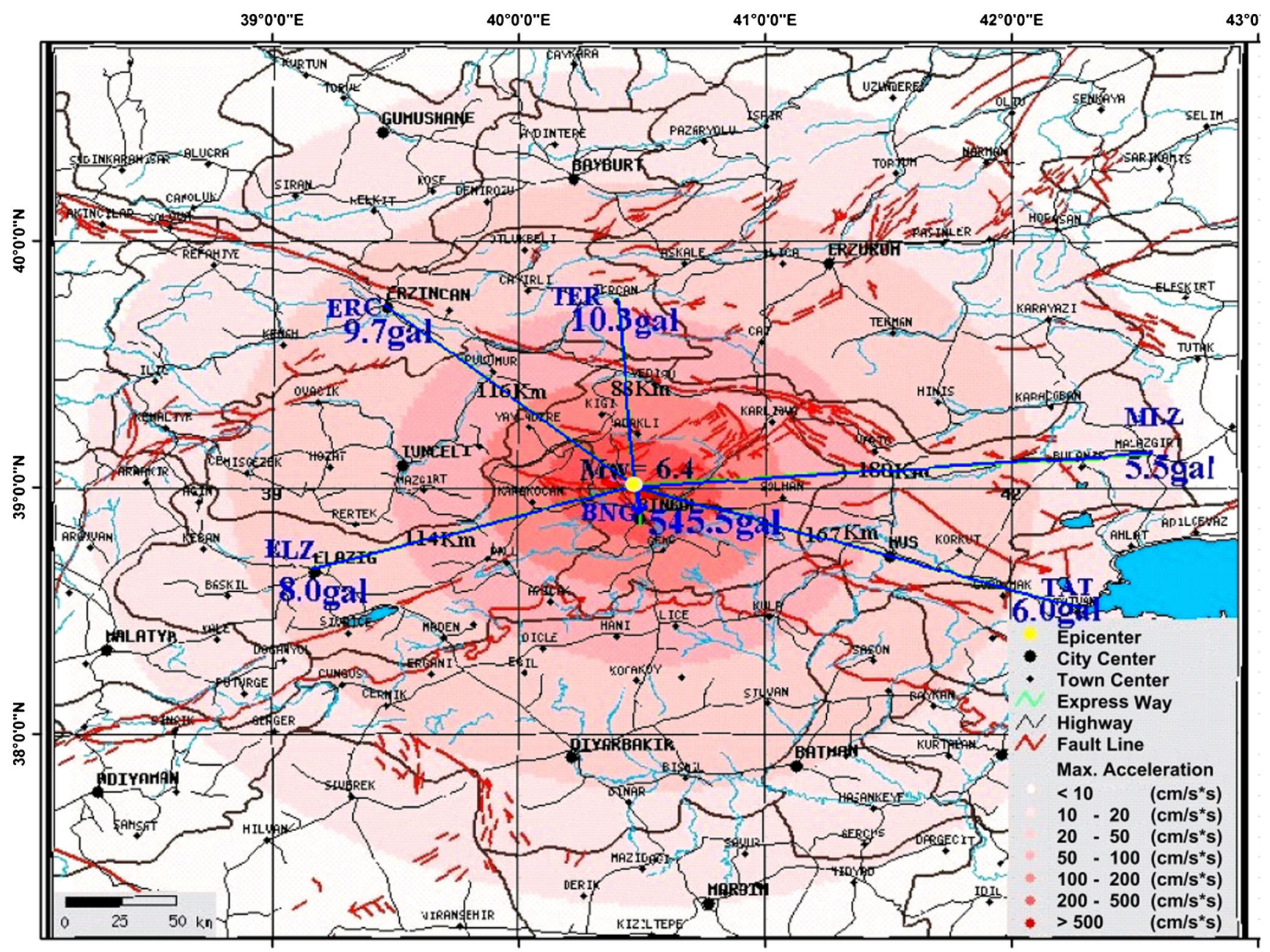

Figure 2. Location of stations recorded the May 1st, 2003 Bingöl earthquake, maximum horizontal peak values and distribution of predicted acceleration values (Bingöl - BNG, Tercan - TER, Erzincan - ERC, Elazı ğ - ELZ, Tatvan - TAT and Malazgirt - MLZ).

city and is on the talus materials containing mainly andesite gravels and blocks of basalt. The stations within the $88-180 \mathrm{~km}$ distances to the earthquake epicenter recorded low acceleration values. These stations, TER, ERC, ELZ, TAT and MLZ, recorded the maximum horizontal acceleration values of $10.3,8.3,8.0,6.0$ and $5.5 \mathrm{~cm} / \mathrm{s}^{2}$, respectively. The $\mathrm{V}_{S 30}$ shear wave velocities $\left(\mathrm{V}_{S 30}=529 \mathrm{~m} / \mathrm{s}\right.$, site category $\mathrm{B}$ according Eurocode-8) obtained by seismic refraction studies around the BNG station and geological section of soil layers are shown in figure 3 . When the 


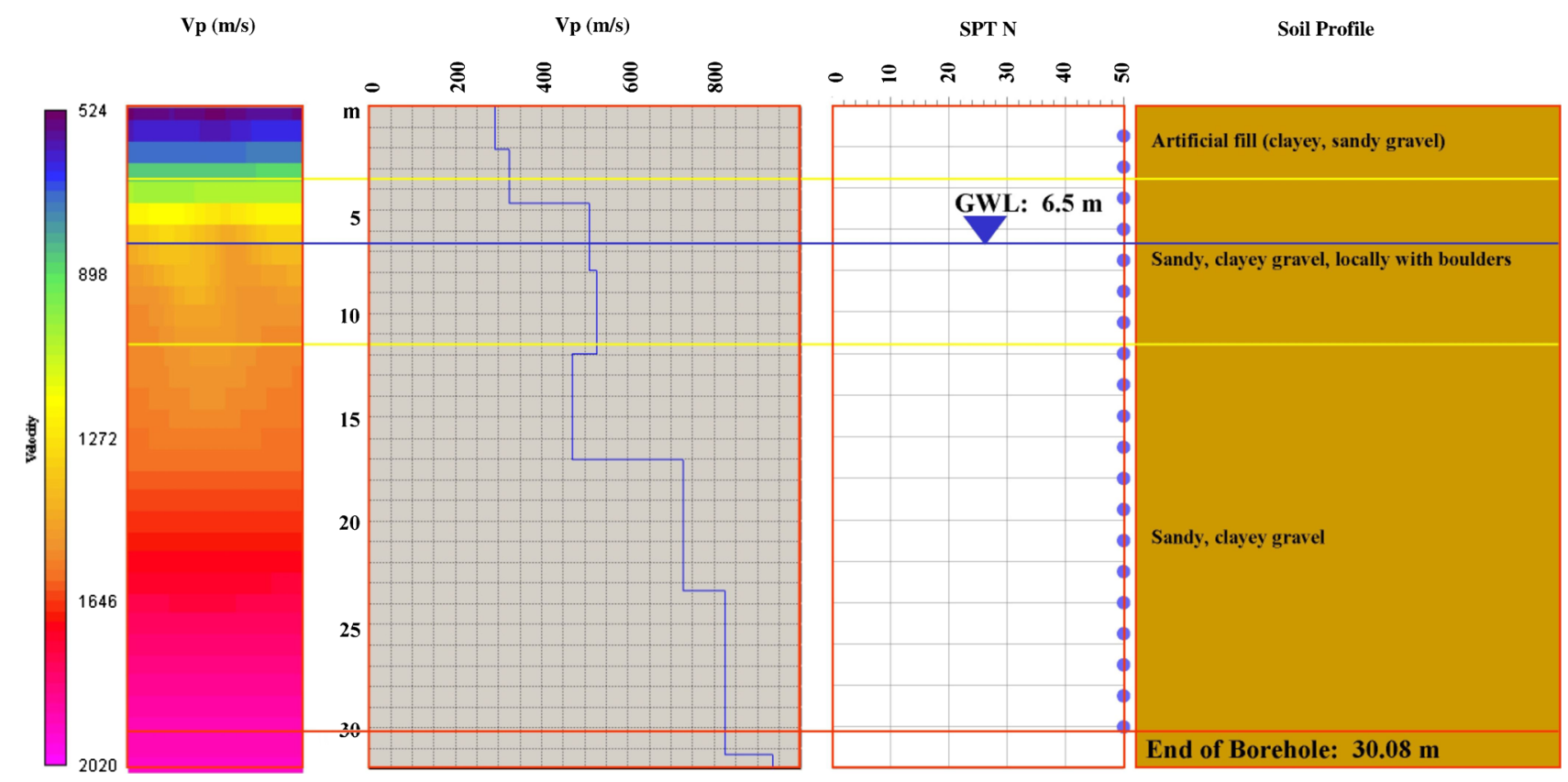

Figure 3. Local soil information for station BNG (http://kyh.deprem.gov.tr).

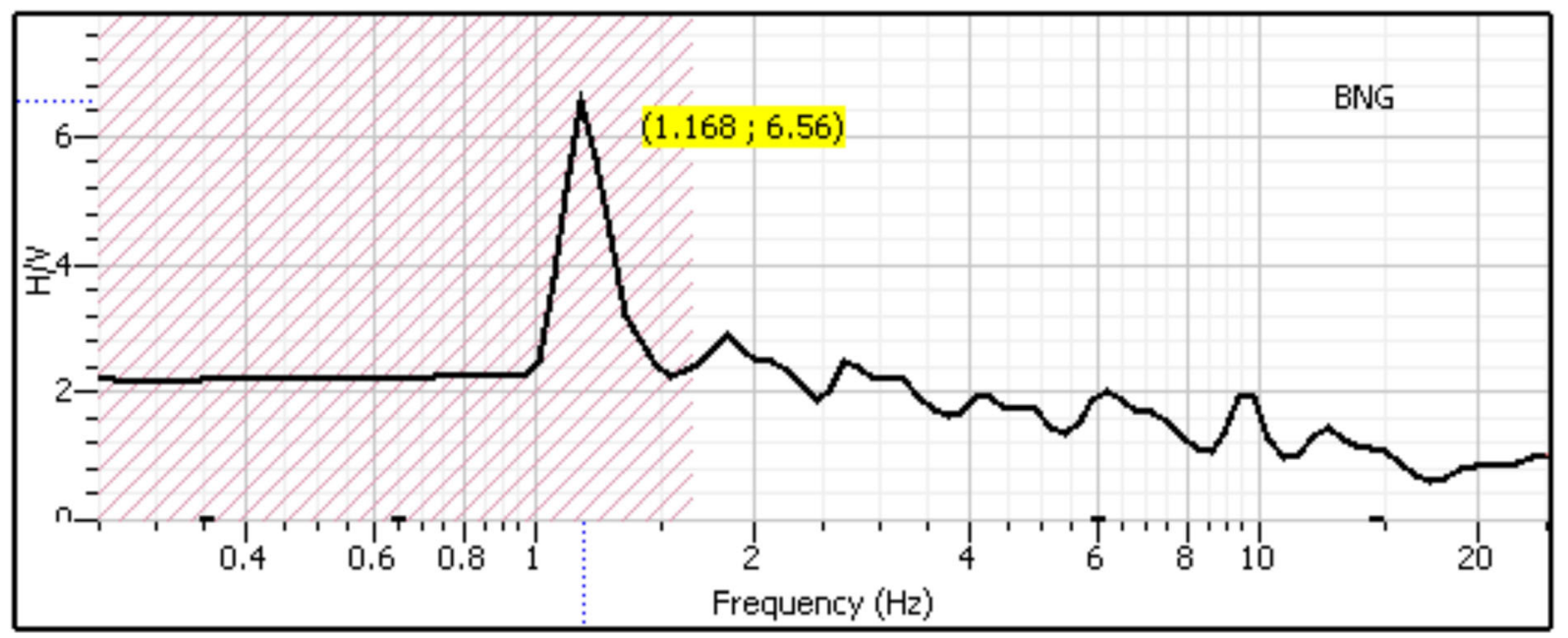

Figure 4. Amplification and dominant frequency values obtained from the acceleration record of the BNG station.

soil profile and seismic velocity values in figure 3 are correlated, it is seen that the upper $25-\mathrm{m}$ soil section consists of Quaternary clay, sand and gravel intercalations. The $\mathrm{H} / \mathrm{V}$ technique was used in determination of amplification and dominant frequency of the Bingöl station ground. A six second data section of the BNG earthquake record was chosen on the S-wave that transmits the maximum energy. This data section was filtered by a Butterworth band-pass with frequency between 0.25 and $25 \mathrm{~Hz}$ and peaks of the data section were also clipped. Amplification and dominant frequency values of the BNG station are shown in figure 4. It can be seen that dominant period of soil was measured to be $0.36 \mathrm{~s}(1.168 \mathrm{~Hz})$ at the $\mathrm{BNG}$ station (figure 5).

No surface rupture was observed during and after the earthquake. However, it was inferred from the distribution of aftershocks, the earthquake could be generated by a fault extending NW-SE. The strike of north-south component of the sensor differs $25^{\circ}$ from the fault plane. Thus, there is a directivity effect between the location of the accelerometer and the direction of fault rupture. 

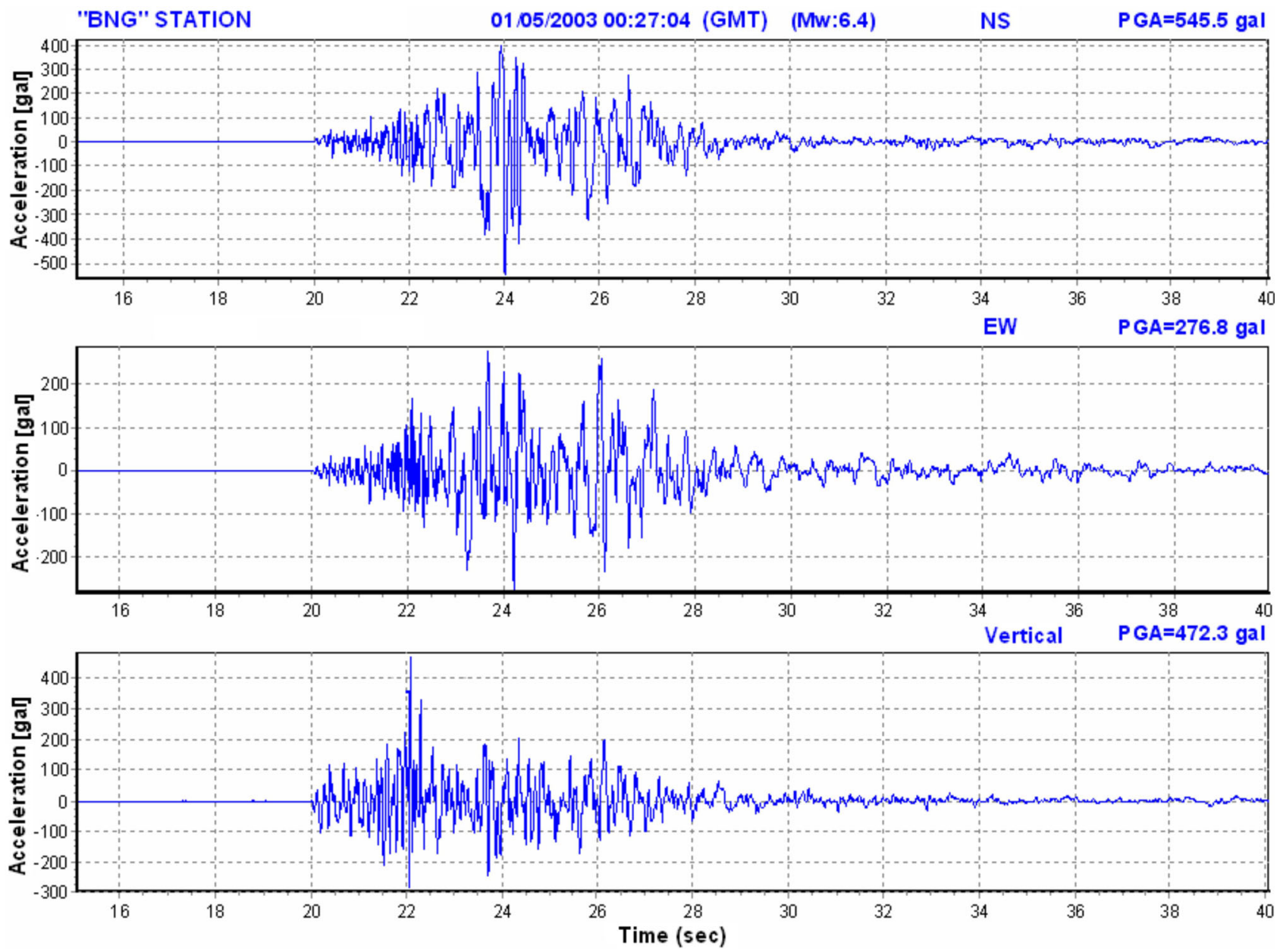

Figure 5. Three components of acceleration record of May 1st, 2003 Bingöl earthquake.

The progression of the fault in the rupture direction causes a long period energy accumulation on the component that is vertical to the fault. Thus, shortening in the duration of the earthquake causes large amplitude in parallel component (Somerville et al. 1997). The high amplitudes in northsouth components of acceleration records might cause forward directivity effect. Baseline-offsetscorrection and Butterworth band-pass filter with $0.2-25 \mathrm{~Hz}$ to main shock acceleration-time record were applied to obtain velocity and displacement wave forms. When the velocity wave form is evaluated, $V_{\max }$ is $34.7 \mathrm{~cm} / \mathrm{s}$ in north-south, $18.6 \mathrm{~cm} / \mathrm{s}$ in east-west and $11.3 \mathrm{~cm} / \mathrm{s}$ in vertical directions (figure 6). When the displacement wave form is evaluated, maximum displacement values are calculated as $9.8,5.1$ and $4.8 \mathrm{~cm}$ in north-south, east-west and vertical directions, respectively (figure 7).

When the acceleration values recorded at other stations are evaluated, a significant attenuation in earthquake waves based on distance and geological structure is noticeable. On the other hand, the earthquake was strong in a narrow zone due to the shallow focus depth of $10 \mathrm{~km}$. Therefore, rapidly attenuated earthquake waves did not affect wide areas. The accelerations below the estimated values based on acceleration-attenuation equations point that the energy attenuation could be high in the region.

The peak acceleration from the Bingöl station record is unusually large and over the empirical curve. Our conclusion is based primarily on the comparison of peak accelerations to some prediction equations. Comparisons were made of the data with ground motion prediction equations (GMPEs) from other earthquakes. The GMPEs used include Boore et al. (1997), Kalkan and Gülkan (2004), Ambraseys et al. (2005), Akkar and Bommer $(2007,2010)$. The comparison is given in figure 8 and shows geometric means of horizontal components of maximum values recorded at stations. According to attenuation equations, the average PGA value is 181 gal for 

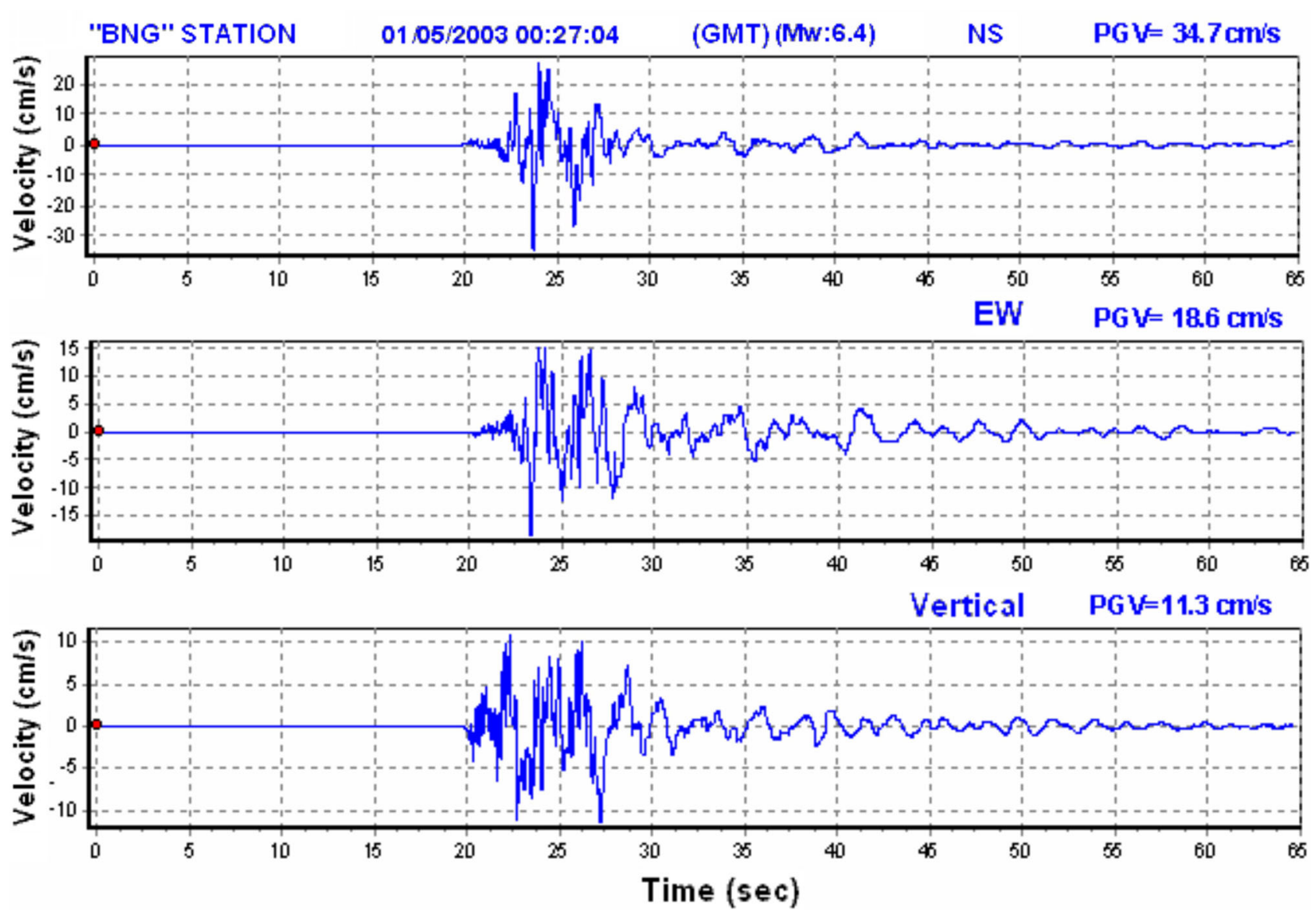

Figure 6. Velocity components of May 1st, 2003 Bingöl earthquake acceleration record.

distance of about $12 \mathrm{~km}$. The observed motion of $545.5 \mathrm{gal}$ is rather above the prediction values. The minor acceleration values recorded at the stations located further than $100 \mathrm{~km}$ were considered insignificant for engineering applications. The largest acceleration value recorded at the BNG station was greater than the estimated value. The recorded acceleration value at the TER station was less than the estimated value. The comparisons with empirical equations of similar recordings suggest that the motions on the BNG station record are unexpectedly large and especially narrow band peak observed in the spectral amplitude at approximately $6.5 \mathrm{~Hz}(0.15 \mathrm{~s})$ is high value for the PGA. Among several explanations for this narrow band amplification, local site response, rupture directivity, or interaction of source corner frequency and local attenuation are also possible explanations for the high-amplitude peak. Table 2 shows the parameters computed by the near source strong motion records of previously occurred earthquakes in Turkey (1992 Erzincan $M_{S}=6.8 ; 1999$ Kocaeli $M_{W}=7.4$ and 1999 Düzce $M_{W}=7.2$ ).

\subsection{Peak vertical acceleration (PVA)}

Peak vertical acceleration is usually accepted as two thirds $(2 / 3)$ of the peak horizontal acceleration (PHA)(Newmark and Hall 1982) for engineering purposes. However, the last studies showed that this relation is quite different. It is indicated that this ratio is greater than one third $(1 / 3)$ for moderate and large magnitude earthquakes and is less than one third $(1 / 3)$ in remote distances (Campbell 1985; Abrahamson and Litehiser 1989). As it is seen in vertical component of the BNG station, the peak acceleration $\left(472 \mathrm{~cm} / \mathrm{s}^{2}\right)$ was greater than the estimated value. In strong motion records close to the epicentre, the horizontal and vertical components can be approximate values. However, as seen in figure 9, the PVA value in the vertical component record is a pulse which jumps at the 22.11 th second of the records. Although, the peak accelerations are important parameters, they do not provide any information about the frequency content and duration of the motion. It is necessary to know the maximum amplitude along with duration and frequency content to characterize ground 

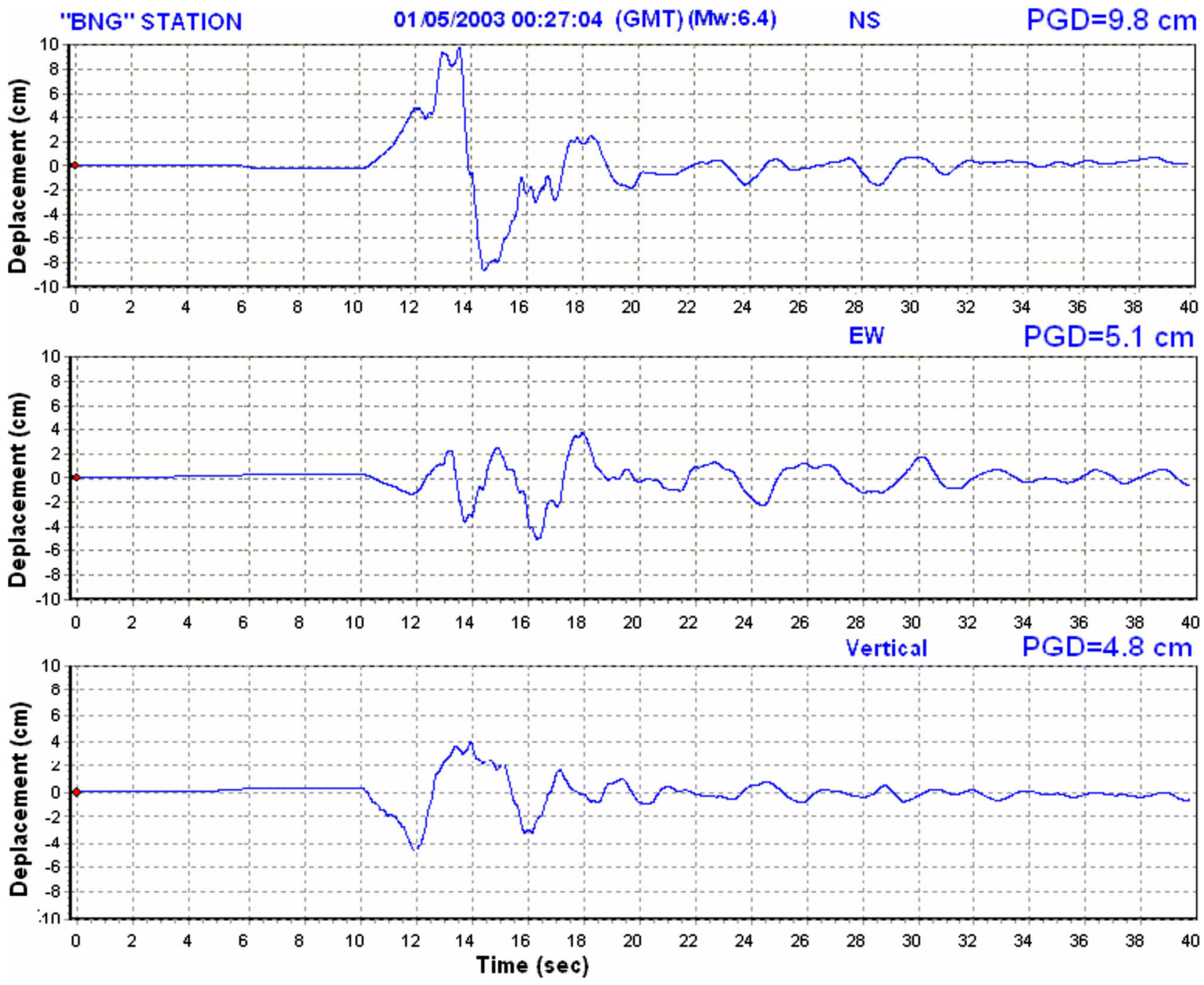

Figure 7. Displacement components of May 1st, 2003 Bingöl earthquake acceleration record.

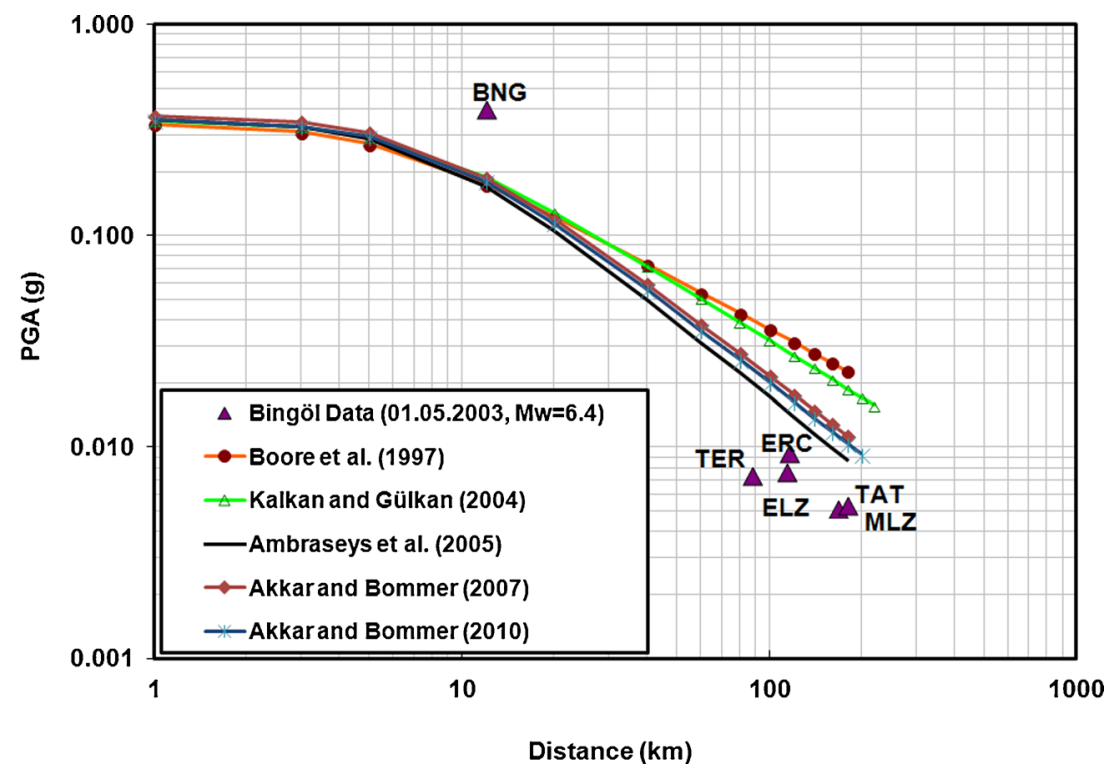

Figure 8. Peak geometric means of horizontal components acceleration values obtained at BNG, TER, ERC, ELZ, TAT and MLZ stations and attenuation-relation proposed by Boore et al. (1997), Kalkan and Gülkan (2004), Ambraseys et al. (2005), Akkar and Bommer (2007, 2010). 
Table 2. Parameters calculated based on the near source strong motion records of previous Turkish earthquakes (D: Epicenter distance to the station, PGA: Peak ground acceleration, PGV: Peak ground velocity, PGD: Peak ground displacement, T: Dominant period, tet: Effective duration, NS: north-south, EW: east-west, V: Vertical).

\begin{tabular}{|c|c|c|c|c|c|c|c|c|c|c|c|c|c|}
\hline \multirow[b]{2}{*}{ Earthquake } & \multirow[b]{2}{*}{ Station } & \multirow[b]{2}{*}{ Hour } & \multirow{2}{*}{$\begin{array}{c}\text { Mag } \\
(\mathrm{GMT})\end{array}$} & \multirow{2}{*}{$\begin{array}{c}\text { Soil } \\
\left(M_{W}\right)\end{array}$} & \multirow[b]{2}{*}{ Depth } & \multicolumn{2}{|c|}{$\begin{array}{c}\text { PGA } \\
\left(\mathrm{cm} / \mathrm{s}^{2}\right)\end{array}$} & \multicolumn{2}{|c|}{$\begin{array}{c}\mathrm{PGV} \\
\left(\mathrm{cm} / \mathrm{s}^{2}\right)\end{array}$} & \multicolumn{2}{|c|}{$\begin{array}{l}\text { PGD } \\
(\mathrm{cm})\end{array}$} & \multirow[b]{2}{*}{$\mathrm{T}(\mathrm{s})$} & \multirow[b]{2}{*}{$t_{\text {et }}(\mathrm{s})$} \\
\hline & & & & & & $\overline{\mathrm{NS}}$ & $\mathrm{EW}$ & $\overline{\mathrm{NS}}$ & EW & $\overline{\mathrm{NS}}$ & $\mathrm{EW}$ & & \\
\hline $\begin{array}{l}13.03 .1992 \\
\text { Erzincan }\end{array}$ & Erzincan & $17: 18$ & 6.8 & Alluvium & 13 & 405 & 471 & 83 & 60 & 20 & 28 & 0.65 & 10 \\
\hline $\begin{array}{l}\text { 17.08.1999 } \\
\text { İzmit }\end{array}$ & İzmit & 00:02 & 7.4 & Rock & 10 & 171 & 225 & 24 & 40 & 17 & 20 & 0.28 & 13 \\
\hline $\begin{array}{l}\text { 12.11.1999 } \\
\text { Sakarya }\end{array}$ & Sakarya & $16: 57$ & 7.4 & Rock & 18 & - & 407 & -45 & 50 & - & 20 & 0.32 & 15 \\
\hline $\begin{array}{l}\text { 12.11.1999 } \\
\text { Düzce }\end{array}$ & Düzce & $16: 57$ & 7.2 & Alluvium & 10 & 408 & 514 & 35 & 52 & 13 & 24 & 0.44 & 13 \\
\hline $\begin{array}{l}\text { 01.05.2003 } \\
\text { Bingöl }\end{array}$ & Bingöl & $00: 27$ & 6.4 & Hard & 12 & 546 & 277 & & 19 & 15 & 6 & 0.33 & 6.5 \\
\hline
\end{tabular}

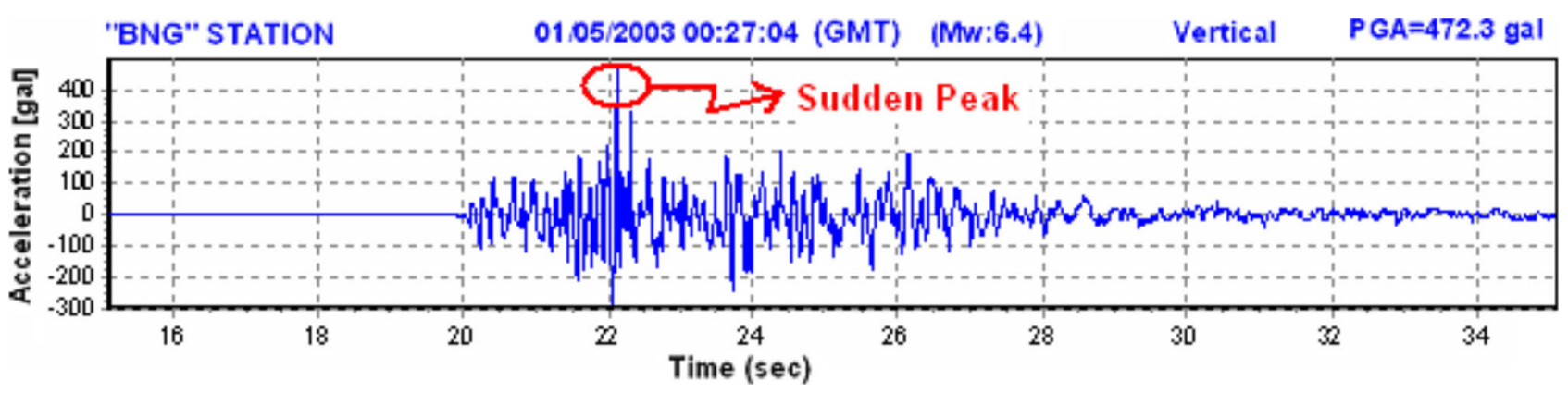

Figure 9. View of sudden acceleration peak pulse seen in vertical component of the main shock recorded in the BNG station.
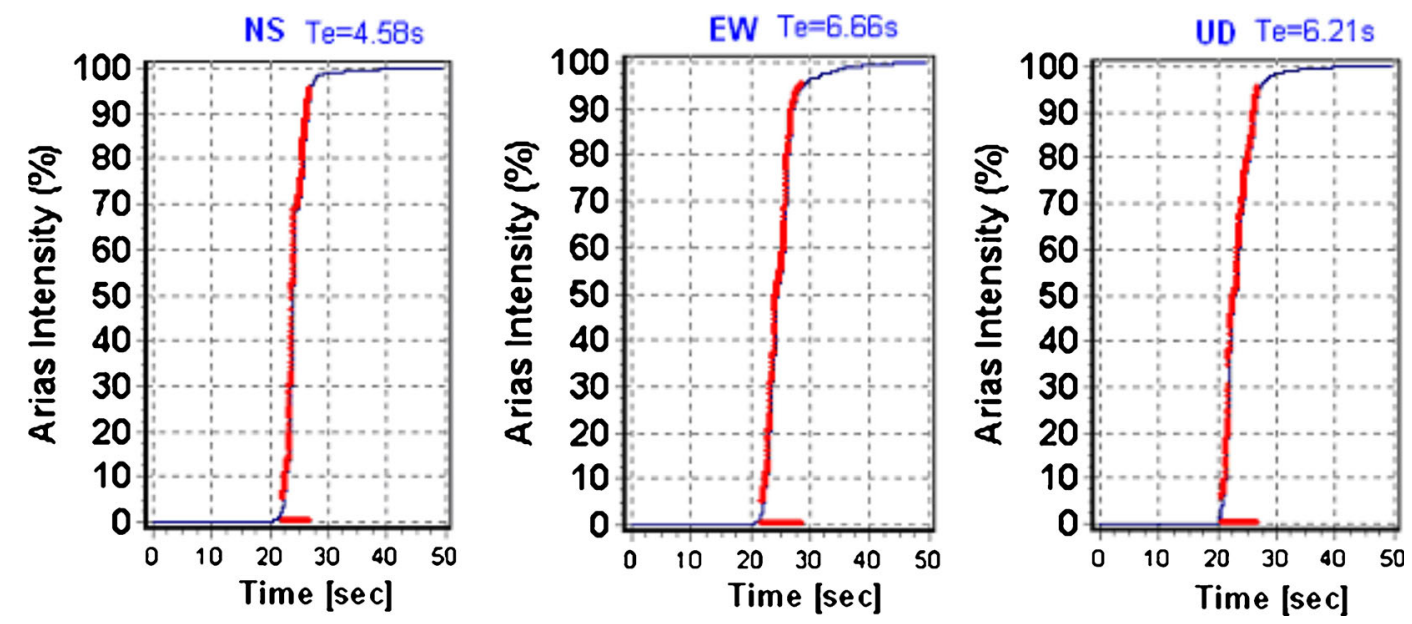

Figure 10. Calculated effective durations Arias intensity increased from $5 \%$ to $95 \%$ for the record taken at the BNG station.

motion properly. Thus, if only the peak value is considered, the maximum peak values can be seen around $330 \mathrm{~cm} / \mathrm{s}^{2}$. There are no effects of these pulses in acceleration spectrums.

\subsection{Duration of strong motion}

Duration of strong motion usually increases with the magnitude (Dobry et al. 1978), intensity 


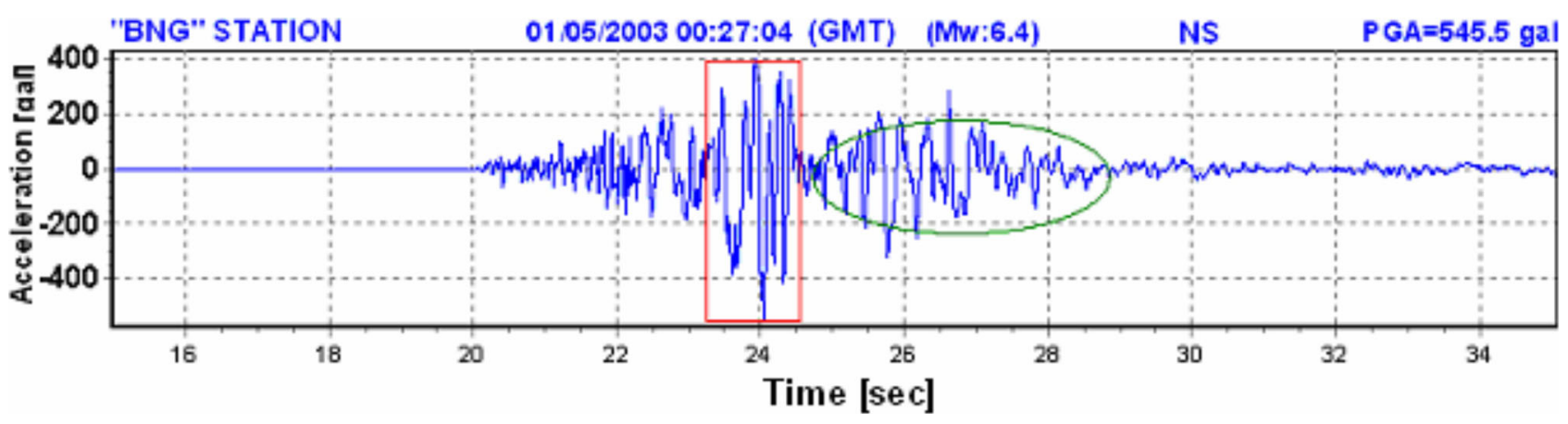

Figure 11. Wave form of north-south component of acceleration record for the BNG station.
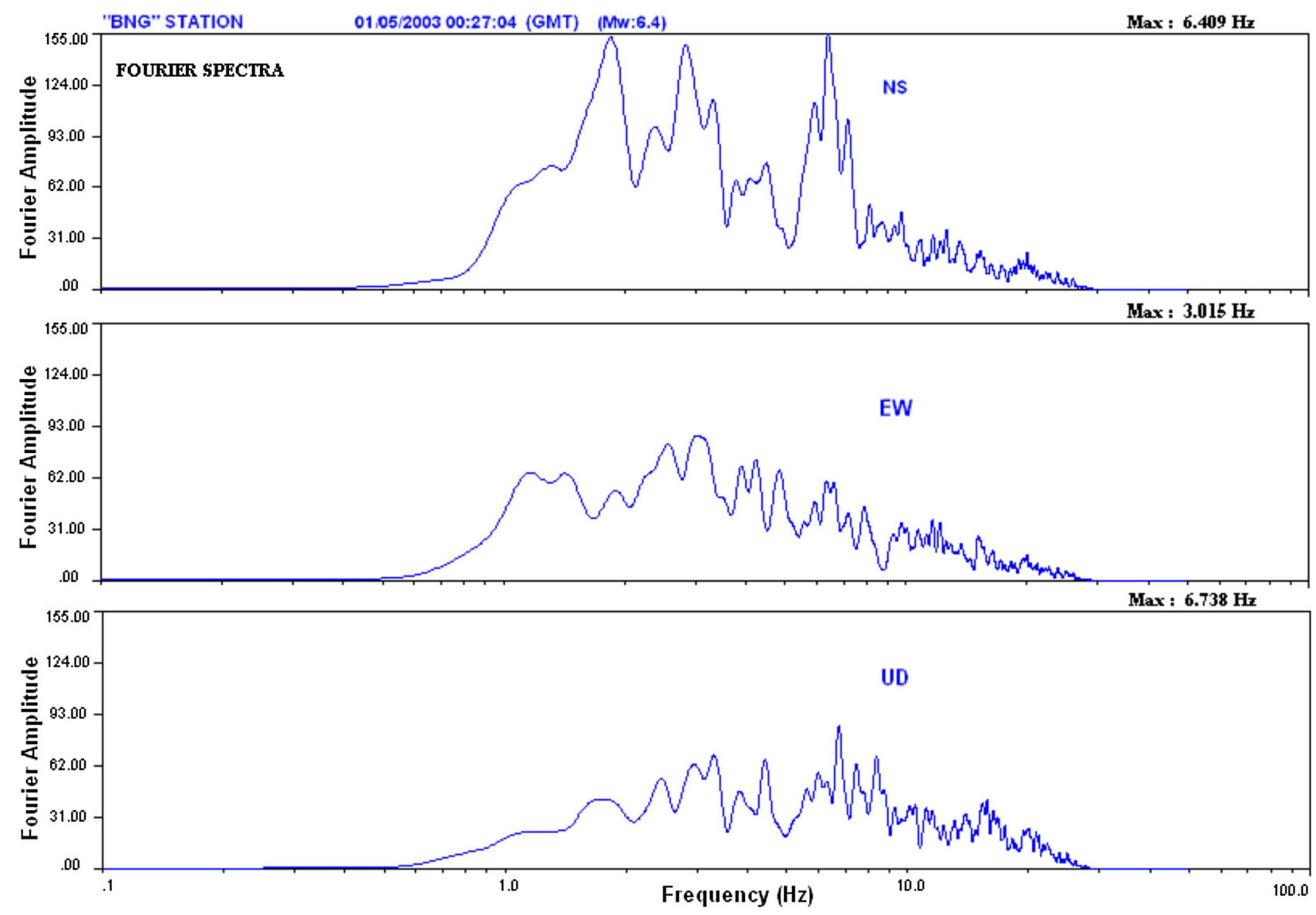

Figure 12. Fourier spectrums of the three components of acceleration records for the BNG station.

and geological conditions (Trifunac and Westermo 1977). Any increase in duration causes more damages in buildings. Duration of a strong motion is one of the parameters defining intensity of strong ground motion and is an effective parameter in engineering applications. Usually, the duration interval between the first and the last acceleration peak is defined for $\geq 50$ gal $(0.05 \mathrm{~g})$ values on the acceleration record (Page et al. 1975). Another approach takes into consideration the total energy obtained by the integral of square of the maximum acceleration. The required time interval for reaching the recommended level of the total energy is defined as the effective duration. The total work of a particle increases from $5 \%$ to $95 \%$ (Husid et al. 1969) or 90\% (Trifunac and Brady 1975) during the effective duration of the strong ground motion. This effective duration is called Arias intensity (Arias 1970) defined by the equation (1).

$$
I_{A}=\frac{\pi}{2 g} \int_{0}^{t r} a^{2}(t) d t
$$




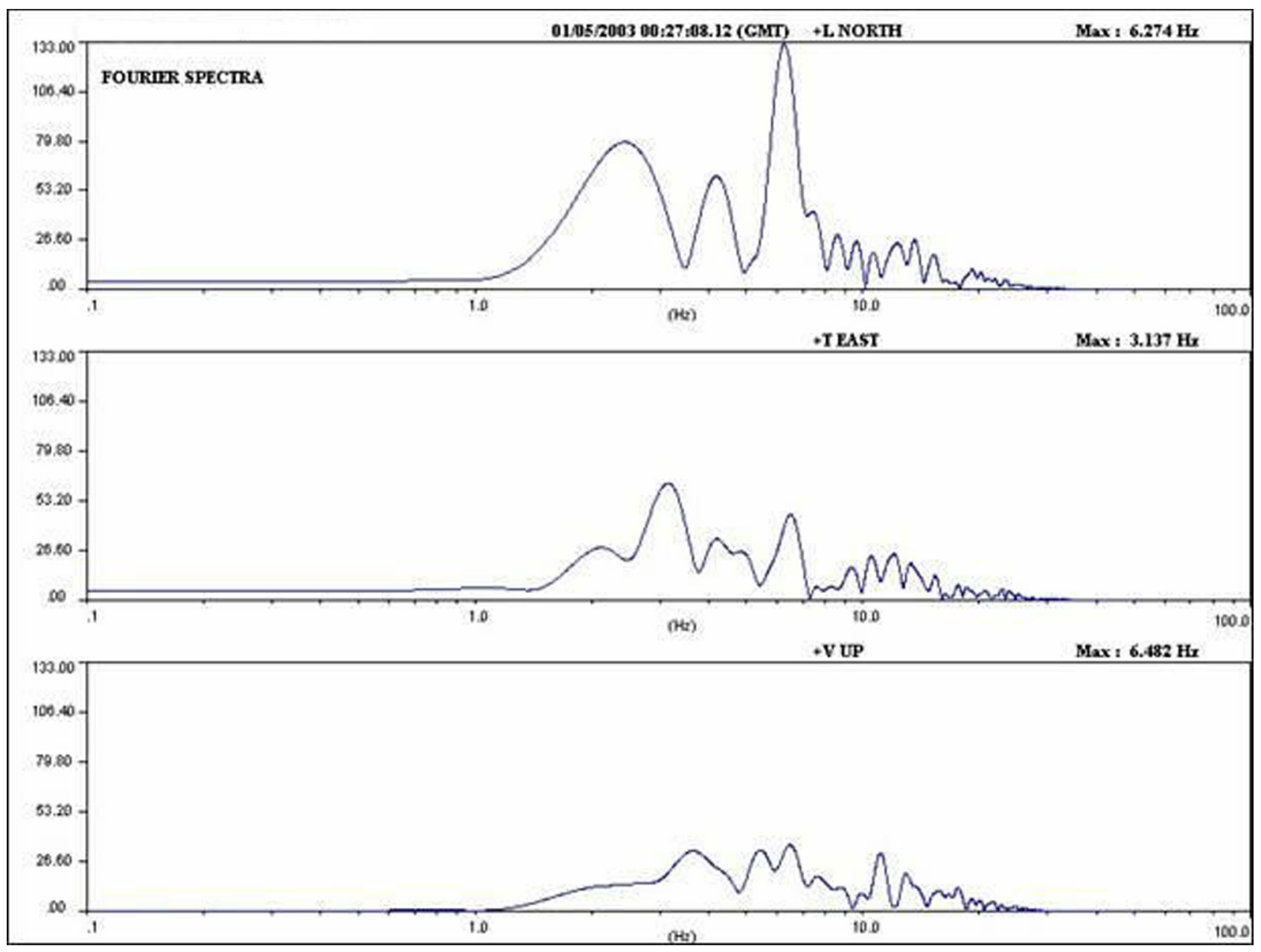

Figure 13. A smoothing process was applied to the maximum spectral amplitudes by a progressive Parzen window with $0.5 \mathrm{~Hz}$ band frequency.
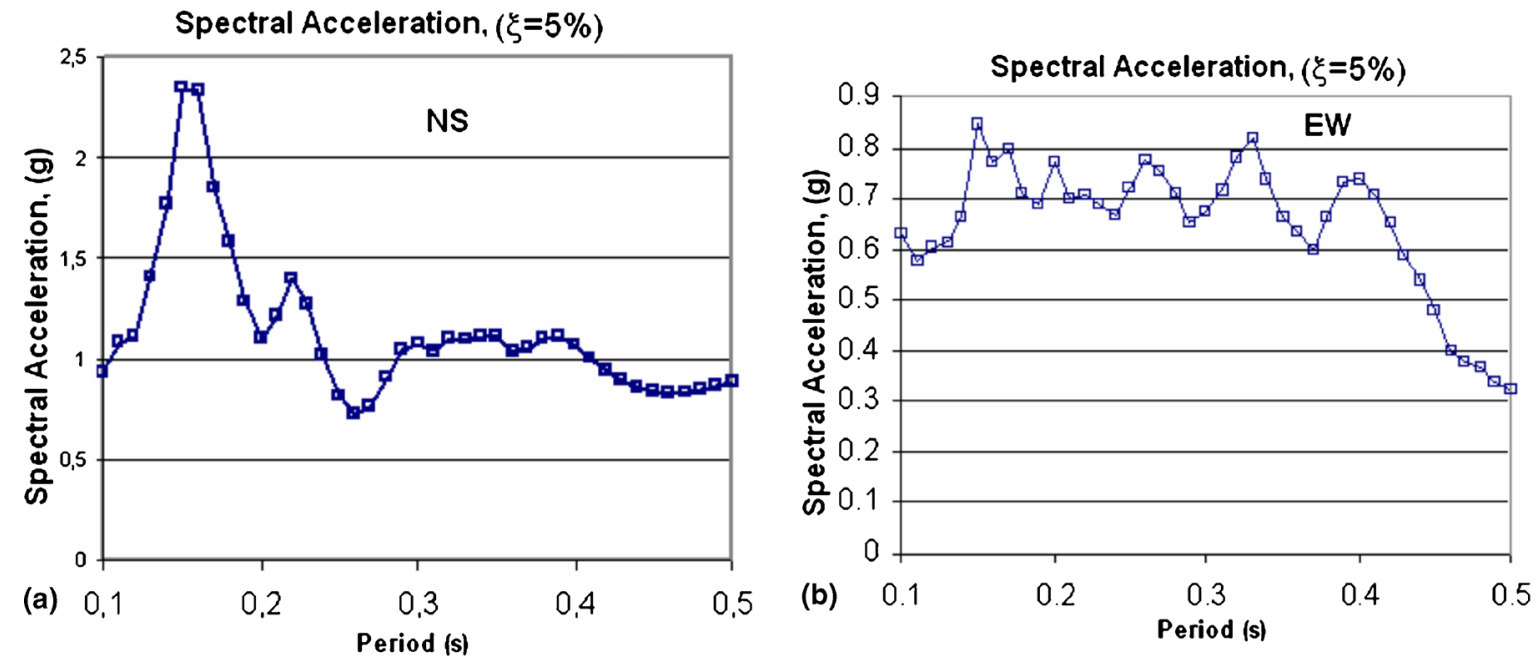

Figure 14. Effective peak acceleration values for the north-south and east-west components of the BNG station record.

where $a$ is the acceleration, $g$ is the gravitational acceleration, $t$ is the time and $t r$ is the length of total recording.
Figure 10 displays the 'effective duration' graphs describing the Arias intensity increase from $5 \%$ to $95 \%$. Effective duration was calculated for 
north-south component as $4.58 \mathrm{~s}$, for east-west component as $6.66 \mathrm{~s}$ and for vertical component as $6.21 \mathrm{~s}$. Although the strong motion of peak acceleration of the Bingöl earthquake was very high, low structural damages can be explained with the short effective duration.

\subsection{Frequency content $(F C)$}

Frequency content (FC) is one of the important factors causing structural damage during an earthquake. It defines how the strong motion amplitude disbands in various frequencies. Fourier amplitude spectrum of an earthquake wave defines which component has the largest amplitude value. Thus, important information for predicting the effect of earthquake waves to structures can be inferred by the help of FC (Ohsaki 1994). Fourier amplitude spectrum of north-south component of acceleration record is shown in figure 11. Three different frequencies $(1.8,2.9$ and $6.4 \mathrm{~Hz}$ ) yield the dominant amplitude (figure 12). Especially, it was determined that $6.4 \mathrm{~Hz}(0.16 \mathrm{~s})$ short period of $\mathrm{S}$ waves for $1.5 \mathrm{~s}$ over 0.3 gal was dominant (figure 13). The smoothing process for the spectrum curves was applied by a Parzen progressive

Table 3. 5\% damping ratio values for the main shock record horizontal component of the BNG station.

\begin{tabular}{|c|c|c|c|c|}
\hline Components & $\begin{array}{c}\text { Maximum } \\
\text { acceleration } \\
\text { (gal) }\end{array}$ & $\begin{array}{c}\text { Spectral } \\
\text { acceleration } \\
\text { (gal) }\end{array}$ & $\begin{array}{c}\text { Effective } \\
\text { acceleration } \\
\text { (gal) }\end{array}$ & $\begin{array}{l}\text { Period } \\
\quad(\mathrm{s})\end{array}$ \\
\hline North-south & 545.5 & 1137 & 455 & 0.15 \\
\hline East-west & 276.8 & 649 & 259 & 0.33 \\
\hline
\end{tabular}

window with $0.5 \mathrm{~Hz}$ band interval. Dominant period of motion shown with an ellipse is calculated to be $0.34 \mathrm{~s}(2.9 \mathrm{~Hz})$. However, east-west component of the record has a dominant period around $0.33 \mathrm{~s}(3.0 \mathrm{~Hz})$. The dominant period of soil obtained from seismic tests and the period values obtained from the Fourier amplitude spectrum of the earthquake are compatible. One of the factors causing structural damage during an earthquake is resonance generated by soils and structures oscillating in the same period. The earthquake did not cause any heavy damage on multi-storey buildings due to vibration of large amplitude acceleration values that lasted $1.5 \mathrm{~s}$ with a low period of $0.16 \mathrm{~s}$ when structure oscillation period is considered as $0.1 \mathrm{~s}$ for each floor of the concrete buildings.

\section{Acceleration response spectrums}

The effect of an earthquake through soils to structures can be defined by the acceleration respond spectrum. The maximum respond value read from acceleration respond spectrum is the absolute acceleration value affecting the structure based on the damping of the structure. Multiplication of this acceleration value by the mass $(\mathrm{m})$ yields the maximum shear strength during earthquakes. Structures absorb some of the energy generated by an earthquake. Velocity spectrum presents the maximum energy loaded on structures. Displacement respond spectrum indicates the largeness of displacement, which is related to the stress in structures. Effective peak acceleration of three components of acceleration record

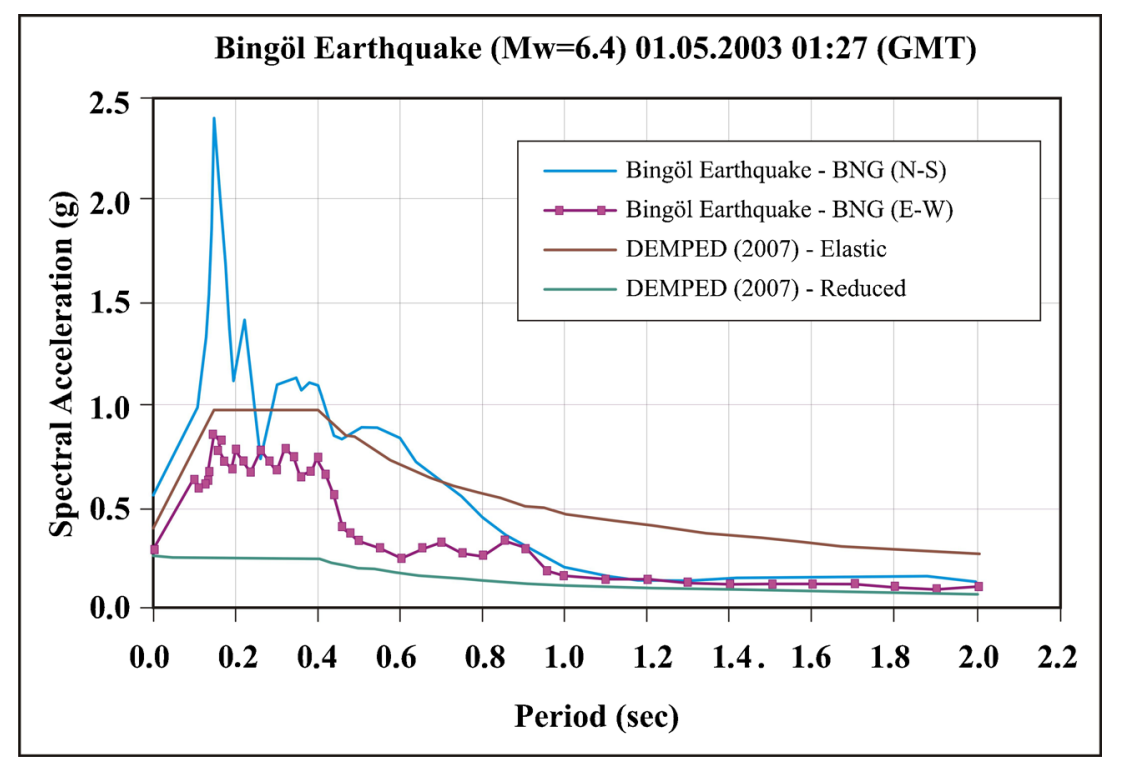

Figure 15. Comparison of the 2003 Bingöl earthquake elastic behaviour acceleration spectrums with Turkish earthquake regulation spectrums. 

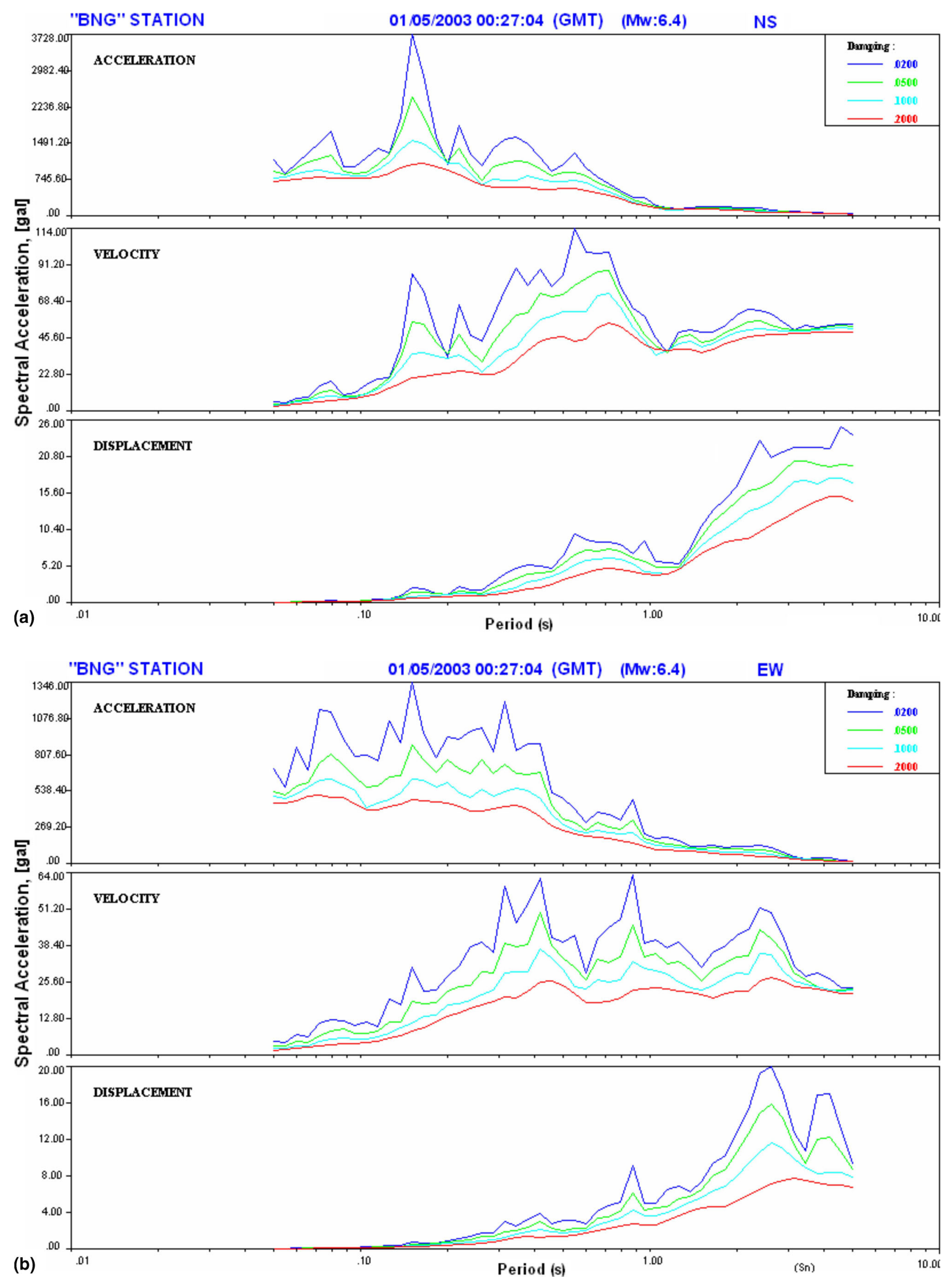

Figure 16. Acceleration, velocity and displacement respond spectrums of horizontal components recorded at the BNG station. 


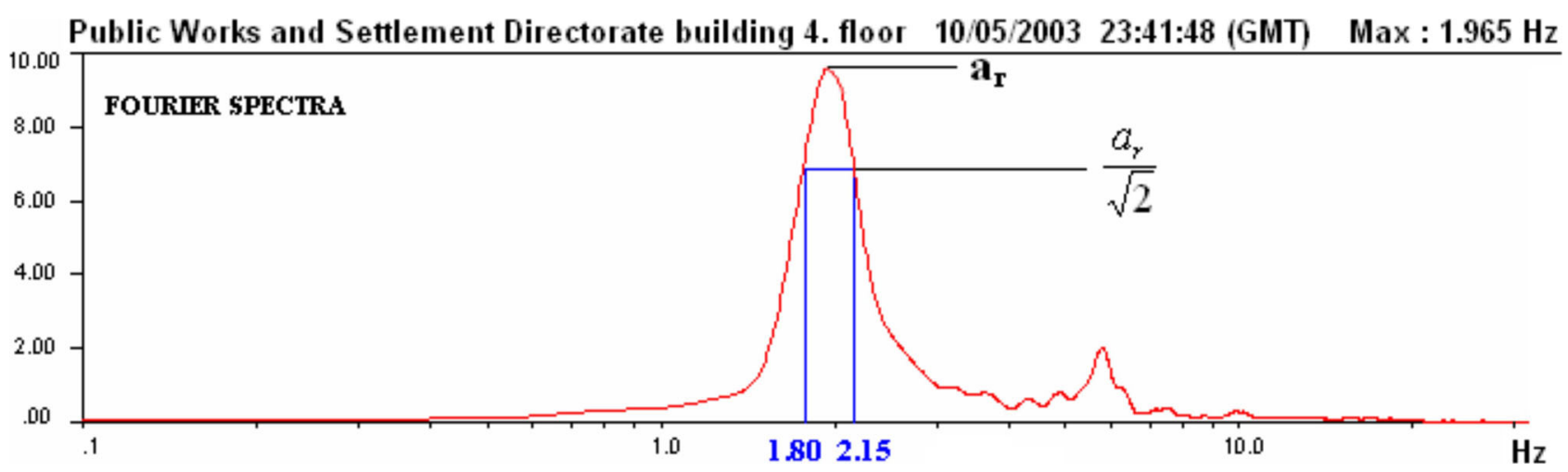

Figure 17. Resonance graphs of acceleration records obtained from accelerometer located on the fourth floor of the Bingöl Prosperity and Housing Management.

at the BNG station was calculated by dividing the average of spectral acceleration between 0.1 and $0.5 \mathrm{~s}$ periods to $2.5 \mathrm{~s}$ (Applied Technology Council 1978). Acceleration respond spectrums are plotted for $5 \%$ damping ratio (figure 14). First, the spectral acceleration was computed for both horizontal components, and then effective acceleration values were obtained according to regulations (DEMPED 2007) (table 3). Especially, north-south component containing high spectral acceleration values has a low period such as $0.15 \mathrm{~s}$. Some important outcomes can be concluded by evaluating acceleration respond spectrum of the earthquake and the damage of collapsed fourstorey school building. Seismic refraction studies on both sides of Capakçukur creek crossing the Bingöl city center defined the dominant period of soil $\left(T_{p}\right)$ as $0.25 \mathrm{~s}$. Rigid structures with short period built on soils with $0.25 \mathrm{~s}$ period could be exposed to damages during an earthquake.

Elastic behaviour spectrum of horizontal component for strong motion record of the BNG station is shown with the horizontal load elastic behaviour spectrum issued by the 1998 Turkish Earthquake Regulations (DEMPED 2007) in figure 15. Additionally, acceleration, velocity and displacement respond spectrums are displayed in figure 16. Damping multiplication factors such as $\mathrm{h}=0.01,0.05,0.1$ and 0.2 were used to obtain maximum acceleration, maximum velocity and maximum displacement values for each plot.

\section{Evaluation of damping}

Deformation of structure parts through vibration of the structure is a very important issue in an earthquake, because structures and their parts have the energy absorption capability. Diminishing of vibration by the energy absorption causes the respond of structure to decrease. Thus, it can be mentioned about the existence of damping in structures (Çelebi and Erdik 1977). There are various damping evaluation methods. The method used in this study defines the damping ratio of a system based on stimulating the system in different frequencies and indicating the amplitude of the magnifying factor in each frequency. Half of the difference between semi-power adjustment ratios or respond frequencies are expressed by the relation of band-width corresponding to the semi-power and damping as in equation (2) (Clough and Penzien 1975).

$$
h=\frac{r_{2}-r_{1}}{2}=\frac{f_{2}-f_{1}}{f_{2}+f_{1}}
$$

$r_{1}$ and $r_{2}$ are the frequency ratios or frequencies corresponding to the $a_{r} / \sqrt{2}$ ordinate of the resonance curve maximum point. The damping ratio of a system can be measured by stimulating the system in different frequencies and determining the amplitude of the magnifying factor for each frequency. An accelerometer set on the fourth floor of the Bingöl Prosperity and Housing Management recorded the aftershocks. The resonance curve was obtained from several acceleration records and the damping percent was calculated as $h=9$ for the building. Figure 17 displays the resonance curve of the records taken by the accelerometer on the fourth floor of the Bingöl Prosperity and Housing Management.

\section{Conclusions}

The main shock acceleration record of the 2003 Bingöl earthquake supplied valuable data for strong motion seismology. The recorded peak acceleration value $\left(545.5 \mathrm{~cm} / \mathrm{s}^{2}\right)$ in north-south direction was greater than the estimated value. This instance could be explained by the proximity of the station to the epicenter and shallow 
focal-depth of the earthquake. The effect of earthquake waves in a narrow zone and fault rupture towards the BNG station caused large acceleration values with low period.

However, the structural damage was not as high and widespread as expected. Many buildings were slightly or moderately damaged during the earthquake. The reasons could be; the recorded peak acceleration was $545.5 \mathrm{~cm} / \mathrm{s}^{2}$ in north-south direction, effective peak acceleration was $455 \mathrm{~cm} / \mathrm{s}^{2}$ and peak velocity value calculated as $34.6 \mathrm{~cm} / \mathrm{s}^{2}$, the short duration $(6.5 \mathrm{~s})$ of the main shock, which caused less energy loading to the structures. Therefore, the structures were not exposed to plastic deformations by a long duration and high amplitude and high frequencies such as $6.4 \mathrm{~Hz}$ occurring especially during the generation of large acceleration amplitudes.

On the other hand, it can be inferred that local soil conditions did not cause a significant amplification, when the strong motion records of the BNG station were evaluated. There were two main factors on this occasion. The first factor was Vs ranging from 550 to $850 \mathrm{~m} / \mathrm{s}$ based on seismic refraction and microtremor studies and the second factor was dominant period of soil, which is defined as $T_{0}=$ $0.21 \mathrm{~s}$. It was observed that the records taken in the stations on soft soils have longer periods. Also, it was noticed that acceleration amplitudes of soft soil stations are greater than the ones on stiff soils and rocks.

\section{Acknowledgements}

The authors would like to extend their gratitude to Engin Çoruh for granting permission to use the software to evaluate the earthquake records and to Mustafa Gürbüz and Celal Çınar for field work contribution, and all of the Strong Ground Motion Working Group.

\section{References}

Abrahamson N A and Litehiser J J 1989 Attenuation of vertical peak acceleration; Bull. Seismol. Soc. Am. 79(3) 549-580.

Akkar S and Bommer J J 2007 Prediction of elastic displacement response spectra in Europe and the Middle East; Earthq. Eng. Struct. Dyn. 36 1275-1301.

Akkar S and Bommer J J 2010 Empirical equations for the prediction of PGA, PGV and spectral accelerations in Europe, the Mediterranean Region and the Middle East; Seismol. Res. Lett. 81 195-206.
Ambraseys N N, Douglas J, Sarma S K and Smith P M 2005 Equations for the estimation of strong ground motions from shallow crustal earthquakes using data from Europe and the Middle East: Vertical peak ground acceleration and spectral acceleration; Bull. Earthq. Eng. 3(1) 1-53.

Applied Technology Council 1978 Tentative provisions for the development of seismic regulations for the buildings; ATC 3-6, Palo Alto, California, USA.

Arias A 1970 A measure of earthquake intensity; In: Seismic Design for Nuclear Power Plants (ed.) Hansen R J, MIT Press, pp. 438-483.

Boore D M, Joyner W B and Fumal T E 1997 Equations for estimating horizontal response spectra and peak acceleration from western North American earthquakes: A summary of recent work; Seismol. Res. Lett. 68(1) $128-153$.

Campbell K W 1985 Strong-motion attenuation relations: A 10-year perspective; Earthq. Spectra 1(4) 759-804.

Clough R W and Penzien J 1975 Dynamics of structures; McGraw-Hill, New York, USA, 63p.

Çelebi M and Erdik M 1977 Introduction of building dynamics; Bull. Earthq. Res. Institute 16 1-121.

DEMPED 2007 (Prime Ministry, Disaster and Emergency Management Presidency, Earthquake Department), Ankara, Turkey.

Dobry R, Idriss I M and Ng E 1978 Duration characteristics of horizontal components of strong-motion earthquake records; Bull. Seismol. Soc. Am. 68 1487-1520.

Husid R, Medina H and Rios J 1969 Analysis de Terremotos Nor-teamericanosy Japoneses; Revista DEL IDIEM 8, Chile.

Kalkan E and Gülkan P 2004 Site-dependent spectra derived from ground motion records in Turkey; Earthq. Spectra 20(4) 853-882.

Newmark N M and Hall W J 1982 Earthquake spectra and design; EERI Monograph Series, Earthquake Engineering Research Institute, California, 103p.

Ohsaki Y 1994 Introductory book for spectral analysis of earthquakes motions; Kajima Press, Japan.

Page R A, Bore D M and Dietrich J H 1975 Estimation of bedrock motion at the ground surface; USGS Professional Paper 941-A.

Somerville P G, Smith N F, Graves R W and Abrahamson N A 1997 Modification of empirical strong ground motion attenuation relations to include the amplitude and duration effects of rupture directivity; Seismol. Res. Lett. 68(1) 199-222.

Tezcan S S and Bal I E 20031 May 2003 Earthquake Preliminary Report; Earthquake Report TDV/DR012 84.

Trifunac M D and Brady A G 1975 A study on the duration of strong earthquake ground motion; Bull. Seismol. Soc. Am. 65(3) 581-626.

Trifunac M D and Westermo B 1977 A note on the correlation of frequency-dependent duration of strong earthquake ground motion with the modified Mercalli intensity and the geologic conditions at the recording stations; Bull. Seismol. Soc. Am. 67 917-927.

Zünbül S, Karakısa S, Milkeriet C, Woith H, Teomen M, Türkoğlu M, Özmen Ö T, Uzun E, Alkan M A and Demirtaş R 2004 Bingöl Earthquake (1 May 2003): Studies of aftershock research; Bingöl Earthquake Report (1 May 2003), Earthquake Research Department, Ankara. 